\title{
地すべり地における地下水排除工 のための地下水動態調查の一事例
}

\author{
梶間厚邦 $^{1}$ - 竹本大昭 ${ }^{2} \cdot$ 春口孝之 $^{3}$ - 佐々木康 ${ }^{4} \cdot$ 奥園誠之 $^{5}$ - 古川浩平 ${ }^{6}$ \\ 1修（工） 日本道路公団 中国支社 松江工事事務所（ $\bar{T} 690-0044$ 島根県松江市浜乃木 8-2-31） \\ ${ }^{2}$ 正会員 修 (工) 山口大学助手 工学部社会建設工学科（テ755-8611 山口県宇部市常盤台 2-16-1) \\ ${ }^{3}$ 株式会社ダ价コン州多外 四国支店 技術課（开790-0952 愛媛県松山市朝生田町 2-8-37） \\ 4 フェロー会員 工博 広島大学教授 大学院工学研究科社会環境システム専攻 \\ （ $739-8527$ 広島県東広島市鏡山 1-4-1） \\ ${ }^{5}$ 正会員 工博 九州産業大学教授 工学部土木工学科（テ813-8503 福岡県福岡市東区松香台 2-3-1) \\ ${ }^{6}$ 正会員 工博 山口大学教授 工学部社会建設工学科（†755-8611 山口県宇部市常盤台 2-16-1）
}

\begin{abstract}
本調査地では, 地すべり地内に道路盛土等を行うことにより, 誘発される地すべり防止目的とした効果 的な地下水位低下を図るために, 地下水の流動状況を適確に把握する必要が生じた. そこで, 本調査地では, ボーリング孔を利用した基礎調查をはじめ流向流速, トレーサー調查等の地下水動態調查を実施し, 地下 水の流動状況を把握した. これらの調査結果及び水質分析, 間隙水圧測定等により明らかとなった被圧地 下水を集中的に排除する方針を地下水排除計画に反映させた. その結果, 地すべりブロック内の地下水位 は大幅に低下し,効果的な地すべり対策を害施することができた.
\end{abstract}

Key Words: land slide,ground-water level survey,groundwater drainage works, confined groundwater

\section{1.はじめに}

国土の大部分が急峻な山地となっている日本列島で は, いたるところに土砂災害危険箇所 ${ }^{1)}$ が分布し, 梅雨 期, 台風期には土砂災害による被害が生じている.

土砂災害の中でも地すべり災害は, 斜面崩壊や土石 流等の災害と比較すると, 突発的に発生する事例は少 なく, 地形, 地質からある程度の災害発生位置を予測で きる.したがって, 地すべり災害の可能性がある地形, 地質が確認できる場合, 予め地すべり対策を行うこと で, 災害を末然に防ぐことが可能となる。

地すべり対策は, 地すべり発生機構を十分に把握し た上で, 確実に地すべり土塊を安定させることが重要 となる.しかしながら, 地すべり発生機構は複雑であり, それらを把握するための調查費も高価であることから, 対策工整備を効率的に実施することは容易ではない. また, 地すべり発生機構は, 地下水位の変動が支配的で あることが多い2).

このような背景から, 多くの地すべり地では, 発生機 構を効率的に把握するための地下水調査が重要であり, その調査結果を的確に施工計画に反映させた効果的な 地すべり対策事業が望まれている.
地すべり対策を効果的かつ効率的に実施するには, 地下水の動態調査 $\left.\left.{ }^{3)}, 4\right), 55,6\right)$ 等により, 推定が困難とされ る地下水の流動状況等を的確に把握し, その調査結果 を踏まえた適切な施工計画の検討が重要である.

近年, 地下水の動態調査法は, 多様化しているが, 従 来行われているボーリング孔を利用した基礎調査でも 様々な地下水の動態状況が把握できるため, 基䃈調査 の重要性も再認識されてきている.

本報告では, 中国横断自動車道計画路線に分布する I 地区の地すべり指定地において, 高速道路整備に対す る地すべり対策のためのボーリング孔を利用した基礎 調査, 比抵抗二次元探查等の地下水動態調査を実施し た. また, 調査の過程で, 地すべりブロック頭部で地下 水が特に胚胎するゾーンが推定され，その主たる原因 はすべり面下位の被圧地下水によるものと考えられ た.

本調査地では, この被圧地下水が地下水位の上昇に 大きく影響し,地すべり土塊の移動に影響を及ぼす原 因と推察されたため, 被圧地下水を集中的に排除する 方針を取り入れた地下水排除計画を立案した. その結 果, 地すべりブロック内の地下水位を大幅に低下させ ることに成功し, 効果的な地すべり対策を実施するこ 


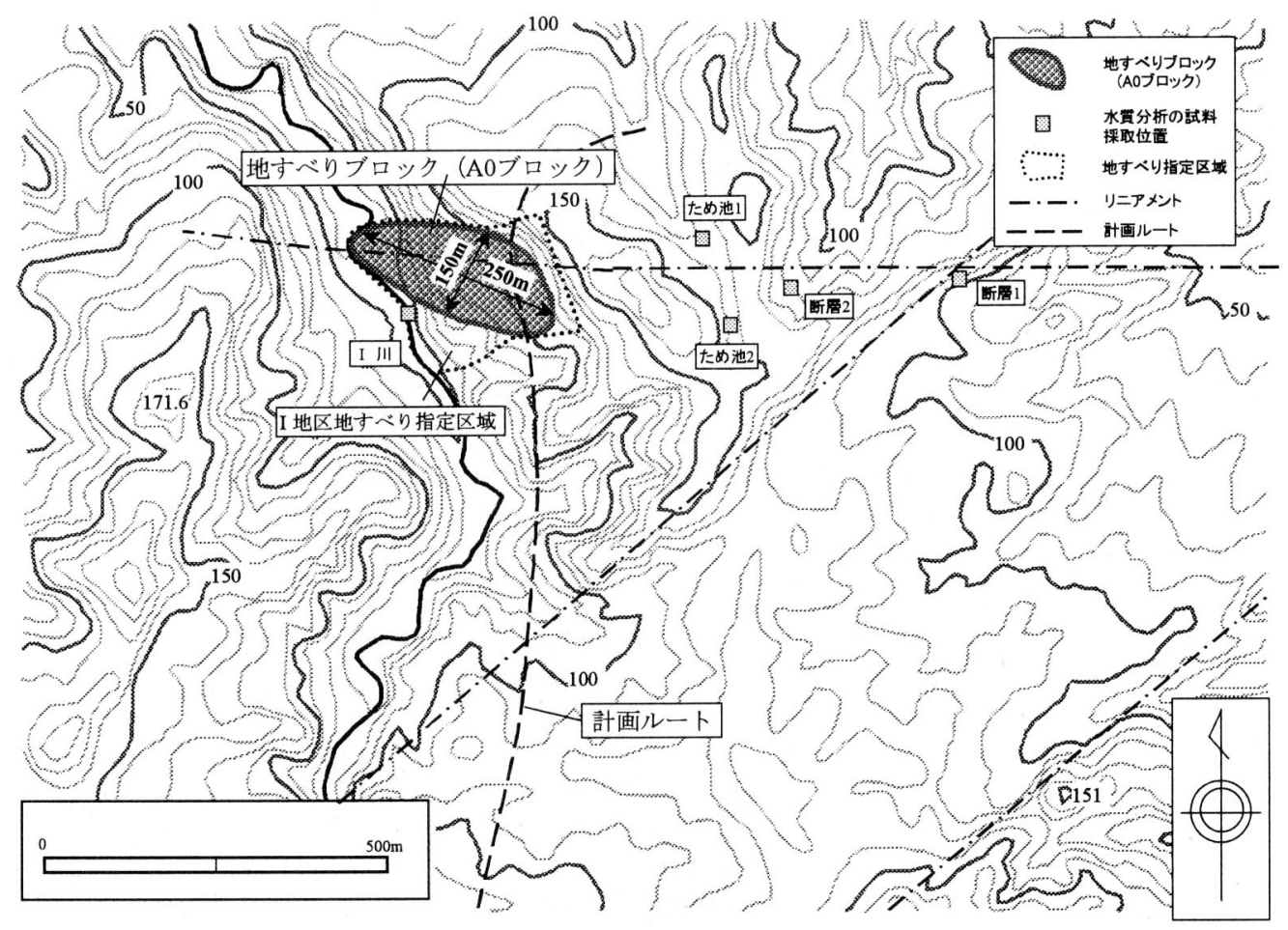

図-1 I 地区周辺の地形

とができた. 以下に, その事例を紹介する.

\section{2. 対象地域の概要}

\section{（1）調查地周辺の地形 ·地質概要}

本調查地は出雲平野の南側に隣接する標高 100 〜 200m の丘陵性山地部に位置しており，その地質は第三 紀の大森層, 久利層の砂岩, 砅岩, 泥岩で構成され, 上 位の大森層は走向がほぼ東西方向で北側へ $10 \sim 15^{\circ}$ で 傾斜する単斜構造を呈している。このような地質状況 から，本調查地周辺は地すべり地として有名であり， 地すべり防止区域が集中的に存在している. 本調查地 はそのうちの一つである I 地区の地すべり指定地であ る. 図-1に I 地区周辺の地形図を示寸.

I 地区は典型的な凹状多丘型の明膫な地すべり地形 である. 地形より推定される地すべりブロック（以下， 「AO ブロック」と表記) の全体の大きさは, 幅約 $150 \mathrm{~m}$, 長さ約 $250 \mathrm{~m}$ である. 地すべり頭部には，馬蹄形の急崖 からなる滑落崖が存在し，滑落崖の直下には頭部凹状 地形が顕著に認められる.この滑落崖は北側に向かっ て $10^{\circ}$ 程度の勾配で傾斜する緩傾斜面の西側端部に位 置する. 中腹には台地状の緩傾斜面が広がり, 竹林と なっている.さらに末端部には急傾斜面が形成されて いる.

\section{（2）地すべりブロックの状況}

詳細な地形測量の結果, 当初推定していた大きな地 すべりブロックの末端付近に幅約 $90 \mathrm{~m}$ ，長さ的 $100 \mathrm{~m}$ の 新たな地すべりブロック（以下，「A1 ブロック」と表 記）の存在が明らかとなった.この地すべりブロック 内では，表面排水用に施工された数筒所のコンクリー 卜水路に切断, 転倒, 食い違いなどの変状が認められ ていることから, 近年, 移動したと考えられる.さらに, このブロックの前面にも, 幅約 70m, 長さ約 $100 \mathrm{~m}$ の地す ベりブロック（以下，「A2 ブロック」と表記）が存在 することが判明した.このブロックの頭部には, 水路の 段差や食い違いが認められるため, 不安定な状態であ ると考えられる.

調查位置と地すべりブロックの範囲を図ー2に示す. 図ー2に示した綻断方向の弾性波探査主測線（D2-2 測 線）上では，過去にボーリング調査を 2 箇所害施して いる.2䇢所ともに深層風化が著しいのが特徴である.

また, 2 箇所のボーリング調査が近接しているにも関 わらず，B1-11 に厚く分布する礫岩が B1-12 には認め られないなど地層は不連続となっている.この地層の 不連続性は，地質的に断層により不連続となっている 場合と，地すべり活動により異種の土塊が混合してい る場合の 2 通りが考えられる.

地すべり面は, ボーリングコアで確認されたすべり 面粘土の位置, パイプ歪計で変位が確認された位置, 


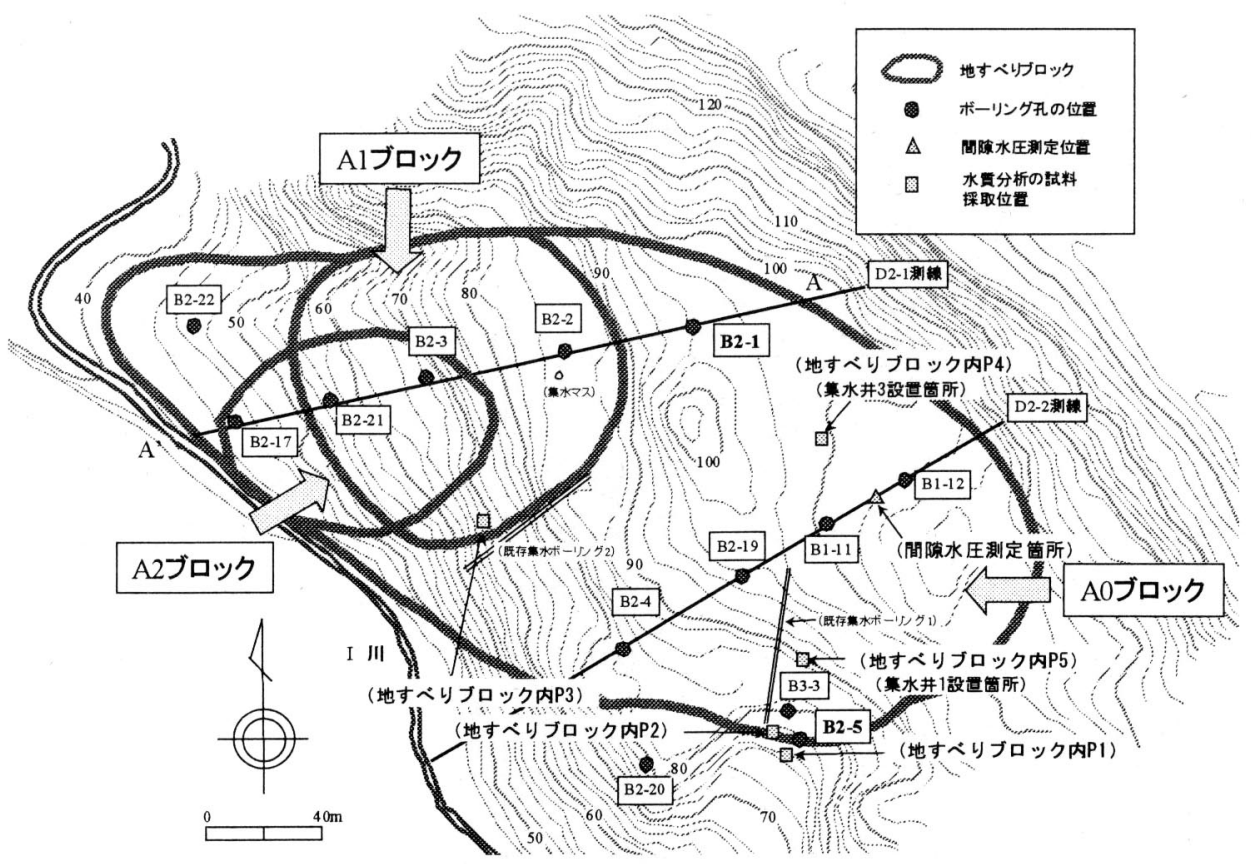

図ー2 調查位置図と地すべりブロックの範囲

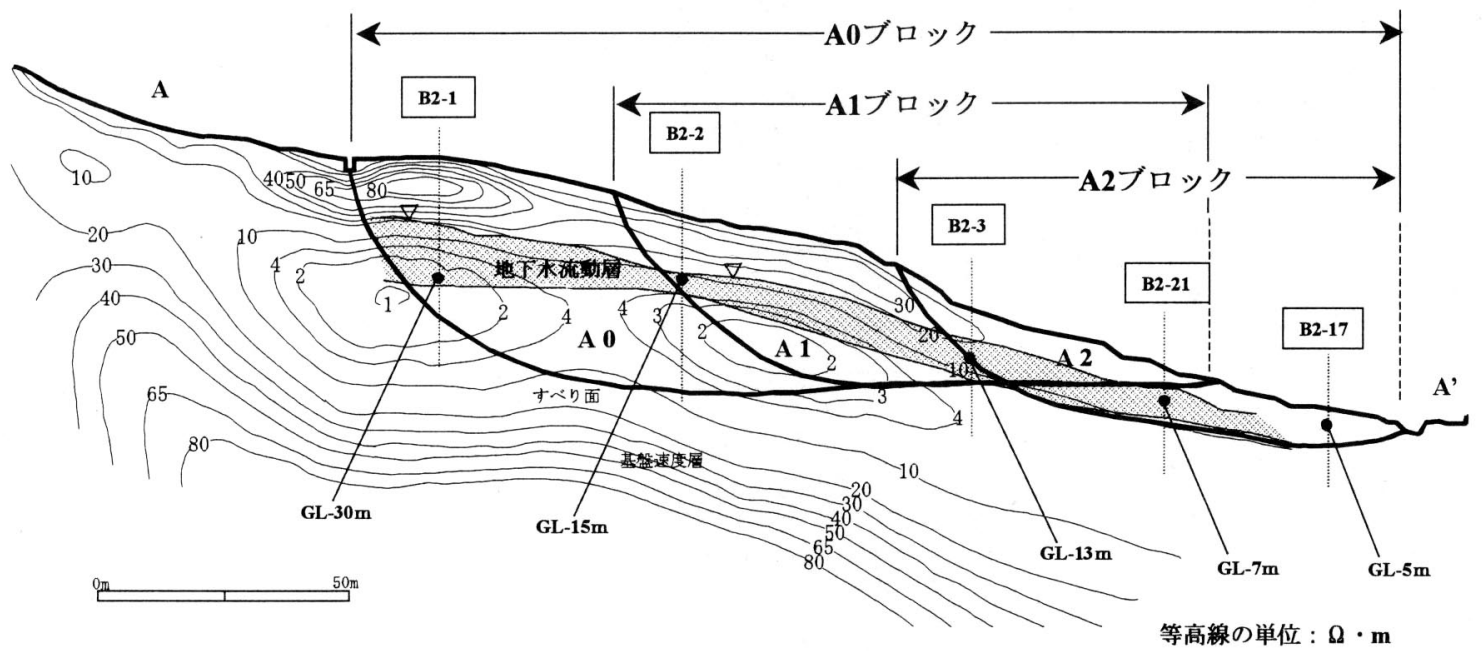

図－3２２-1 測線の断面と地下水流動層の分布

強風化帯〜風化帯の中に挟まれる粘土層の位置と弾性 波探查結果による基盤速度層上面の位置等のデータを 参考に図ー3のように推定した.

弾性波探查の結果より,この地すべりブロック (D2-1 測線上）では，基盤速度層に低速度帯(幅 $5 \sim 12.5 \mathrm{~m}$ 程 度)が数多く検出されている.これらの低速度帯はその 平面的連続性加々て, $\mathrm{N} 72^{\circ} \mathrm{W} \sim \mathrm{N} 75^{\circ} \mathrm{W}$ の破砕帯 群と解釈できる. このような低速度帯が多く分布する ということは，元来この区域が地質的に劣悪であった ことを意味しており，このことがこの区域に樑層風化 や比較的規模の大きい地すべりを発生させる要因にな
ったものと考えられる.

\section{3. 地下水流動調查と地下水排除工の検討}

\section{（1）地下水流動状況把握のための調査}

本調査においては, A0 ブロックにおいて地下水の状 況を把握するために表ー1 に示されているボーリング 調查, 地下水検層, 地下水位測定, 弾性波探查, 比抵 抗二次元探査を行った. 各々の観測結果から図一2に 示してある D2-1 測線の断面図を図示する(図一3 参照). 
表-1＼cjkstart各ボーリングと地下水観測結果

\begin{tabular}{|c|c|c|c|c|c|c|}
\hline \multirow{2}{*}{$\begin{array}{l}\text { ボーリング } \\
\text { 番号 } \\
\end{array}$} & \multirow{2}{*}{ 掘削中の孔内水位 } & \multirow{2}{*}{ 地下水㭘層結果 } & \multicolumn{3}{|c|}{ 地下水観測結果 } & \multirow{2}{*}{$\begin{array}{l}\text { 降雨と地下水 } \\
\text { の関倸 } \\
\end{array}$} \\
\hline & & & 最高水位 & 最低水位 & 変動幅 & \\
\hline $\begin{array}{c}\text { B2-1 } \\
\text { (D2-1測線) }\end{array}$ & $\begin{array}{l}\text { すべり面を境に,水位が約 } \\
6.0 \mathrm{~m} \text { 上昇 }\end{array}$ & $\begin{array}{l}\text { 深度 } 17 \mathrm{~m} \sim 28 \mathrm{~m}, 37 \sim 39 \mathrm{~m} \text { の間に比抵抗 } \\
\text { が增大 }\end{array}$ & $\begin{array}{c}\text { GL-7.38m } \\
(89.58 \mathrm{~m})\end{array}$ & $\begin{array}{c}\text { GL-16.04m } \\
(80.92 \mathrm{~m})\end{array}$ & $8.66 \mathrm{~m}$ & $\begin{array}{l}\text { 水位は降雨に対してよ } \\
\text { く反忘し上昇するが, } \\
\text { 減衰傾向は緩やか }\end{array}$ \\
\hline $\begin{array}{c}\text { B2-2 } \\
\text { (D2-1測線) }\end{array}$ & $\begin{array}{l}\text { すべり面を境に, 水位が } \\
\text { 約5.0m上梨 }\end{array}$ & $\begin{array}{l}\text { 墚度15（地下水面）〜17mの間に比抵 } \\
\text { 抗が増大 } \\
\text { 流動層は地下水面付近にあり, 樑度 } \\
\text { 18m以深では, 比抵抗の変化なし }\end{array}$ & $\begin{array}{l}\text { GL- } 9.67 \mathrm{~m} \\
(75.60 \mathrm{~m})\end{array}$ & $\begin{array}{l}\text { GL-15.15m } \\
(70.12 \mathrm{~m})\end{array}$ & $5.48 \mathrm{~m}$ & $\begin{array}{l}\text { 水位は降雨に対してよ } \\
\text { く反応,水位の昇降傾向 } \\
\text { はシャープ }\end{array}$ \\
\hline $\begin{array}{c}\text { B2-3 } \\
(\mathrm{D} 2-1 \text { 測線 })\end{array}$ & \begin{tabular}{|l|} 
掘削中の水位は深度9.90m \\
前後にあり, ほとんど変 \\
化しない
\end{tabular} & $\begin{array}{l}\text { 梁度11 (地下水面) } 15 \mathrm{~m} \text { の間に比抵抗 } \\
\text { が増大,約60分でほぼ真水に近い状態に } \\
\text { なる } \\
\text { 梁度 } 15 \mathrm{~m} \text { 付近のすべり面以深は, 比抵 } \\
\text { 抗の変化なし }\end{array}$ & $\begin{array}{l}\text { GL-3.74m } \\
(62.04 \mathrm{~m})\end{array}$ & $\begin{array}{c}\text { GL-9.95m } \\
(55.83 \mathrm{~m})\end{array}$ & $6.21 \mathrm{~m}$ & $\begin{array}{l}\text { 水位は降雨に対してよ } \\
\text { く反忘,水位の昇降傾向 } \\
\text { はシャープ }\end{array}$ \\
\hline $\begin{array}{c}\text { B2-21 } \\
\text { (D2-1測線) }\end{array}$ & $\begin{array}{r}\text { 水位は哚度 } 1.60 \mathrm{~m} \text { 付近と高 } \\
<， \text { ほとんど変化しない } \\
\downarrow\end{array}$ & 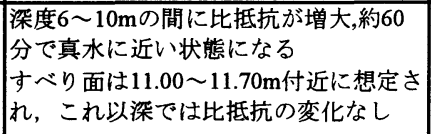 & $\begin{array}{l}\text { GL- } 1.32 \mathrm{~m} \\
(51.61 \mathrm{~m})\end{array}$ & $\begin{array}{c}\text { GL } 1.72 \mathrm{~m} \\
(51.72 \mathrm{~m})\end{array}$ & $0.40 \mathrm{~m}$ & $\begin{array}{l}\text { 水位は深度 } 1.3 \sim 1.7 \mathrm{~m} の \\
\text { 範囲でほとんど変化し } \\
\text { ない }\end{array}$ \\
\hline $\begin{array}{c}\text { B2-17 } \\
\text { (D2-1測線) }\end{array}$ & \begin{tabular}{|l|} 
水位は深度2.25〜3.26mと \\
高く変動は少ない \\
\end{tabular} & $\begin{array}{l}\text { 樑度3〜 7mの間に比抵抗が変化 } \\
\text { すべり面の真上に当たる深度 } 5 \sim 6 \mathrm{~m} \text { の } \\
\text { 間は特に比抵抗が変化 }\end{array}$ & $\begin{array}{l}\text { GL- } 2.88 \mathrm{~m} \\
(41.36 \mathrm{~m})\end{array}$ & $\begin{array}{c}\text { GL-3.48m } \\
(40.76 \mathrm{~m})\end{array}$ & $0.60 \mathrm{~m}$ & $\begin{array}{l}\text { 掘削中及び定期観測の } \\
\text { 結果,水位は深度 } 2 \sim 4 \text { と } \\
\text { 高い }\end{array}$ \\
\hline $\begin{array}{c}\text { B2-19 } \\
\text { (D2-2湘線) }\end{array}$ & \begin{tabular}{|l|} 
水位は当初 $3.20 \mathrm{~m}$ に有り深 \\
度 $13.0 \mathrm{~m}$ まで低下
\end{tabular} & $\begin{array}{l}\text { 深度13〜22mの間に比抵抗が変化 } \\
24 \mathrm{~m} \text { 以樑（すべり面より梁い）では比 } \\
\text { 抵抗の変化なし }\end{array}$ & $\begin{array}{l}\text { GL- } 11.87 \mathrm{~m} \\
(83.00 \mathrm{~m})\end{array}$ & $\begin{array}{c}\text { GL-13.06m } \\
(81.81 \mathrm{~m})\end{array}$ & $1.19 \mathrm{~m}$ & $\begin{array}{l}\text { 水位は, 深度 } 12 \sim 13 \mathrm{~m} \\
\text { 付近にあり変動幅は小 } \\
\text { さい,降雨に対しての反 } \\
\text { 忘は鈍い }\end{array}$ \\
\hline $\begin{array}{c}\mathrm{B} 2-4 \\
\text { (D2-2測線) }\end{array}$ & $\begin{array}{l}\text { 掘削中の水位は深度 } 9.80 \mathrm{~m} \\
\text { 前後にあり, ほとんど変 } \\
\text { 化しない }\end{array}$ & $\begin{array}{l}\text { 樑度9 (地下水面) } 10 \mathrm{~m} \text { の間に比抵抗 } \\
\text { が変化 } \\
\text { 梁度 } 10 \mathrm{~m} \text { 以樑では, 比抵抗の変化なし }\end{array}$ & $\begin{array}{l}\text { Gl-1.37m } \\
(81.92 \mathrm{~m})\end{array}$ & $\begin{array}{c}\text { GL-10.13m } \\
(73.16 \mathrm{~m})\end{array}$ & $8.76 \mathrm{~m}$ & $\begin{array}{l}\text { 水位は降雨に対してよ } \\
\text { く反応,水位の昇降傾向 } \\
\text { はシャープ }\end{array}$ \\
\hline B2-5 & \begin{tabular}{|l|} 
水位は深度2.25〜3.25m \\
高く変動は少ない \\
\end{tabular} & $\begin{array}{l}\text { 哚度4〜9mの間に比抵抗が変化 } \\
\text { すべり面の真上に当たる墚度 } 4 \sim 6 \mathrm{~m} \text { } \\
\text { 間は特に比抗が変化 }\end{array}$ & $\begin{array}{l}\text { GL- } 0.88 \mathrm{~m} \\
(76.87 \mathrm{~m})\end{array}$ & $\begin{array}{c}\text { GL-3.18m } \\
(74.57 \mathrm{~m})\end{array}$ & $2.30 \mathrm{~m}$ & $\begin{array}{l}\text { 水位は, 媣度 } 1 \sim 3 \mathrm{~m} の \\
\text { 範囲でほとんど変化し } \\
\text { ない,降雨に対しての反 } \\
\text { 忘も鈍い }\end{array}$ \\
\hline B2-20 & $\begin{array}{l}\text { 水位は深度3.01m付近と高 } \\
\text { く，ほとんど変化しない }\end{array}$ & 全体に比抵抗の変化なし & $\begin{array}{l}\text { GL-2.78m } \\
(69.00 \mathrm{~m})\end{array}$ & $\begin{array}{c}\text { GL-2.89m } \\
(68.89 \mathrm{~m})\end{array}$ & $0.11 \mathrm{~m}$ & $\begin{array}{l}\text { 掘削中及び定期観測の } \\
\text { 結果,水位は深度 } 2.80 \mathrm{~m} \\
\text { 付近でほとんど変化し } \\
\text { ない }\end{array}$ \\
\hline B2-22 & \begin{tabular}{|l|} 
すべり面を境にわずかな \\
水位の昇が認められ, \\
その後水位は約1.5m低下 \\
\end{tabular} & $\begin{array}{l}\text { 深度4（地下水面）～9mの間に比抵抗 } \\
\text { が增大 } \\
\text { 哚度 } 10 \mathrm{~m} \text { 以哚では，比抵抗の変化なし }\end{array}$ & $\begin{array}{l}\text { GL-3.49m } \\
(42.40 \mathrm{~m})\end{array}$ & $\begin{array}{c}\text { GL- } 4.84 \mathrm{~m} \\
(41.05 \mathrm{~m})\end{array}$ & $1.35 \mathrm{~m}$ & $\begin{array}{l}\text { 水位は媣度 } 3.49 \sim 4.84 \mathrm{~m} \\
\text { の範囲でほとんど変化 } \\
\text { しない,降雨に対する反 } \\
\text { 応も鈍い }\end{array}$ \\
\hline
\end{tabular}

地下水位測定を実施した結果, 各ボーリング孔のそ れぞれで表ー1に示すような特徴が見られた. その代表 例として, 以下に地すべりブロック頭部に位置する B2-1, B2-5 における地下水位の変動状況を図一4に示 す. 図-4 は, 上からの棒グラフで降水量を示し, 折れ 線グラフで孔内水位を示している.

B2-1 の地下水位は, 降雨に良く反応して急激に上昇 するが, 降雨後の低下に際しては比較的緩やかである. 特に地下水位のピークの遅れが平均して 2 日後であり， 地すべりブロックだけではなく, その背後からの補給 水の影響が考えられる. さらに，B2-1 では, ボーリン グ掘削時において, すべり面を抜いた際に, 地下水位 が急激に上昇したことから,すべり面直下に被圧地下 水が存在する可能性も考えられた. B2-5 に関しては, 降雨とは全く無相関に一定の状態を保っており, 常時 地下水が流入していると考えられる.
次に比抵抗二次元探查, 地下水検層を行い, 以下のよ うに地下水流動層を推定した. まず, 本調査地では, 比 抵抗二次元探査を D2-1, D2-2, D2-3 測線について行い, 比抵抗値の差から透水層の分布を把握した. 調査結果 の一例として, 地すべり主測線方向（D2-1 断面）の比 抵抗值の分布を図一 3 に示す.図一 3 において比抵抗值 の分布は, 等高線 (単位 $\Omega \cdot \mathrm{m}$ ) で示しており, 比抵抗值 の低いゾーンが透水層と推定できる. 透水層は, 主に地 表面から $20 \mathrm{~m} \sim 40 \mathrm{~m}$ 付近に分布し, 特に $\mathrm{A} 0, \mathrm{~A} 1$ ブロック のすべり面下位及び各地すべりブロックの背後に存在 することが分かる.

上記で推定した透水層の中で, 地下水が流動する層 を明確にするため, 各ボーリング孔で地下水検層を行 った. 調查結果の代表例（B2-1, B2-2, B2-3）を図-5に 示す. 図一5 は, 縦軸に深度, 横軸に比抵抗値の変動量を 示し, 地下水が流動している深度を把握することがで 


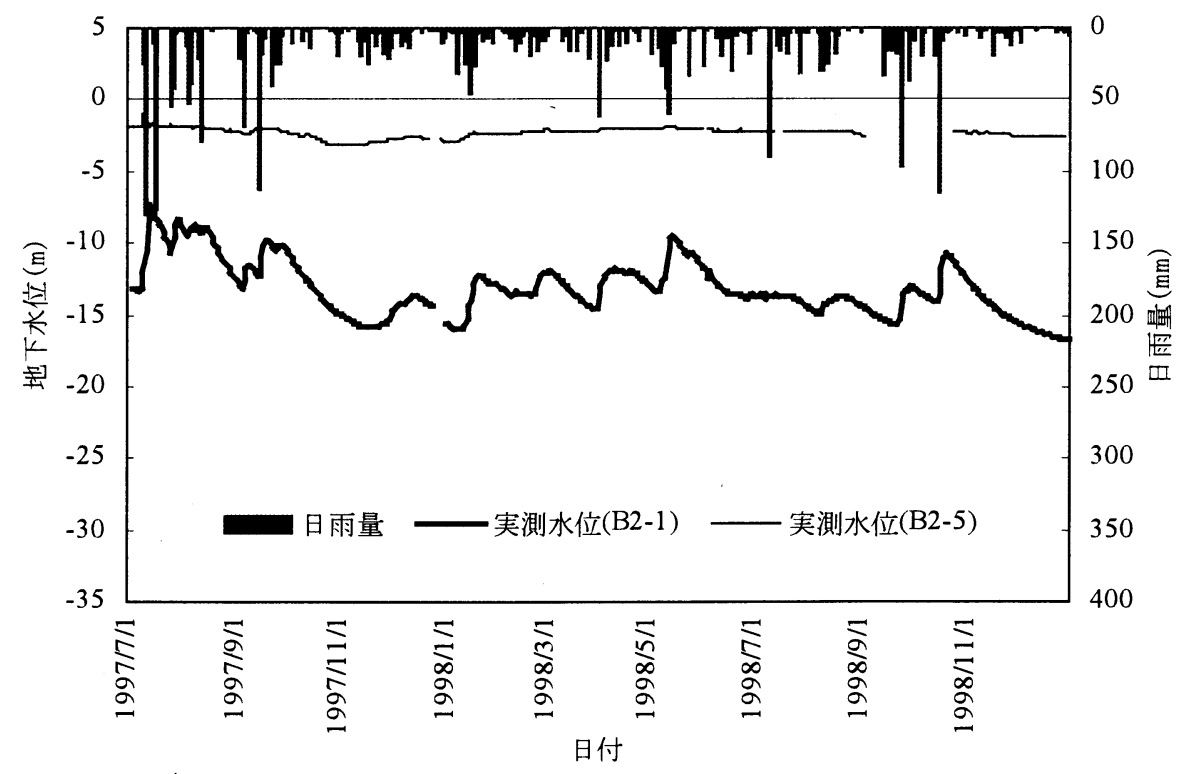

図-4 地下水位変動状況

きる. 例えば B2-2 では, 深度 $15 \mathrm{~m} \sim 17 \mathrm{~m}$ で比抵抗值が増 大していることから,この深度で地下水の流動が著し いといえる. また, その他の地下水検層結果は, 表一1に 示すとおりである.

これらの地下水検層結果から, 地下水の流動速度は 表一2 のようになった. 表一2 から明らかなように, 地 下水の流動速度は, 図一3で示した比抵抗值が低い深度 で大きいことが分かる. したがって, 図一 3 に示した透 水層では, 地下水が流動していると考えられる. 以上よ り,地下水流動層を図ー3のように推定した.

\section{(2) 地下水排除計画の検討と追加調査の提案}

本調查地では, 地下水検層及び比抵抗二次元探査か ら, 地下水帯水層が分布していることが確認された. また, 地下水検層結果から地下水面表層部に分布する 地下水は流動速度が速く, 図一5 のグラフでも時間の 経過に伴って, 比抵抗值が大きくなっている. 更に地 下水位の変動状況から, 降雨直後の急激な水位変動は, 降雨の影響によるものと考えられる. これらの理由に より, 地すべりブロック内の地下水は, 排除が可能な地 下水と考えられる. したがって, 本調査地では, 地下水 排除工を主体とした対策工を整備する案が最良の方法 であると判断した.

ボーリング調査や比抵抗二次元探査の結果では, 地 すべりブロック頭部に地下水が胚胎していると推察さ れる. 本調査地のように表層の地形が平坦で地すべり ブロックが大きい場合, 地すべりブロック頭部の地下 水は, 地下水面まで縦井戸を下げて, 集水ボーリングを
実施することで, 50 〜 $70 \mathrm{~m}$ 程度の短い集水ボーリングで 効率的な排除が可能である. 仮に地表から地すべり頭 部の地下水を排除するには, 100m 以上の横ボーリング が必要であり, 実用性は低い. したがって, 本調査地で は, 集水井を整備する案が実用的かつ効果的であると 考えられる.

そこで, 集水井の効果を確認するため, 試験的に地下 水流動層に対して集水ボーリングを実施したところ, 降雨時に $18 \mathrm{l} / \mathrm{min}$ の湧水を確認し, 集水ボーリングの 排水効果が期待できた. この結果より集水井を施工す る配置計画の検討を行った。

集水井を計画に際して, 本報告では地下水流動調查 結果やボーリングコアの観察, 水位観測結果を基に地 下水位を推定し, 安定解析を行った. 本調查地は, 地す べり指定区域であるため, 集水井による地下水位低下 は, 設計上 $3 \mathrm{~m}$ とする必要があった. したがって, 安定解 析は水位低下 $3 \mathrm{~m}$ として行い, 所定の安全率を満足する 設計を行った.

次に, 集水井の配置計画を立てる上での問題点とそ の解決策及び追加調査すべき項目を以下に示す.

\section{a) 地下水の起源の問題}

ボーリング孔 B2-1 の掘削において,すべり面を抜い たときに水位が上昇したこと, 比抵抗二次元探査結果 より,すべり面下位及び背後の比抵抗值が低いことか ら, すべり面下位及び背後に被圧地下水の存在が考え られる. したがって, 地すべり地内の地下水が降水起 源であるか, 地すべりブロックの背後からの地下水か, あるいは地下深部からの被圧地下水であるかを明らか 


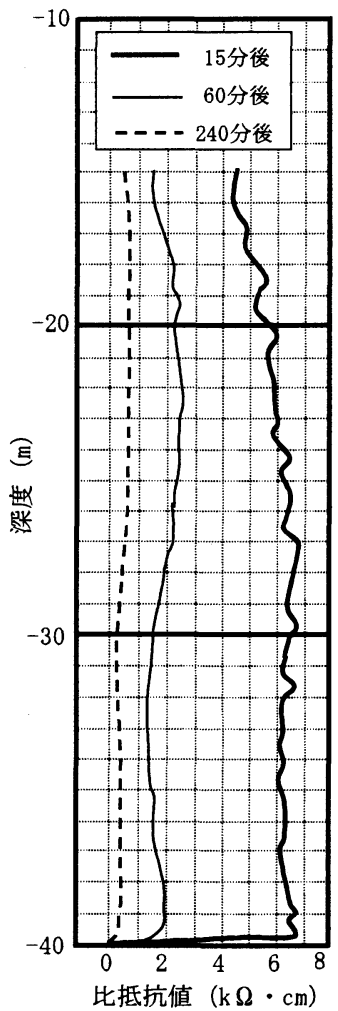

(a) B2-1

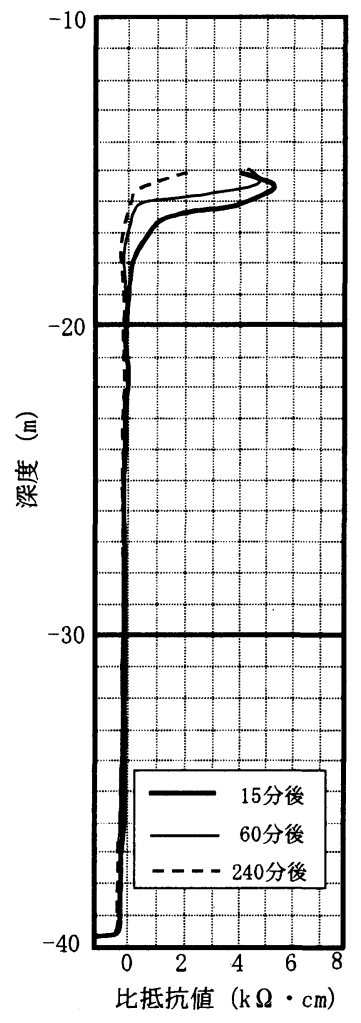

(b) B2-2

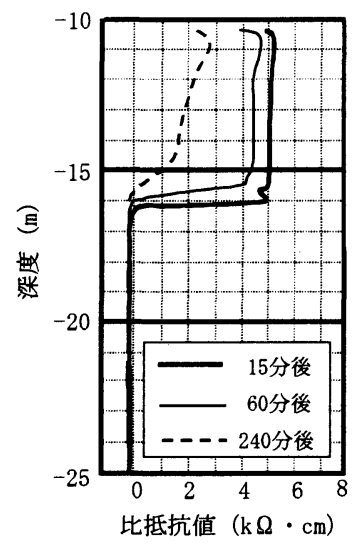

(c) B2-3

図-5 地下水検層結果（B2-1, B2-2, B2-3）

表－2 地下水検層結果による地下水の流動速度

\begin{tabular}{cc}
\hline $\begin{array}{c}\text { ホーリソグ及び } \\
\text { 計測深度 }\end{array}$ & 地下水の流動速度 $(\mathrm{cm} / \mathrm{sec})$ \\
\hline \hline $\mathrm{B} 2-1(\mathrm{GL}-30 \mathrm{~m})$ & $3.2 \times 10^{-3}$ \\
$\mathrm{~B} 2-2(\mathrm{GL}-15 \mathrm{~m})$ & $3.6 \times 10^{-2}$ \\
$\mathrm{~B} 2-3(\mathrm{GL}-13 \mathrm{~m})$ & $1.4 \times 10^{-2}$ \\
$\mathrm{~B} 2-21(\mathrm{GL}-7 \mathrm{~m})$ & $2.4 \times 10^{-2}$ \\
$\mathrm{~B} 2-17(\mathrm{GL}-5 \mathrm{~m})$ & $1.4 \times 10^{-2}$ \\
\hline
\end{tabular}

にする必要がある.

まず，地すべりブロック内の水収支の算定を行い， 集水域からの水の供給量と, 地下水位変動状況から地 すべり地内の地下水量を比較し, 水収支を降雨のみで 説明できるかについて検討を行う。 またそれに伴い， 間隙水圧測定, 水質分析, 年代測定などの追加調査に より地下水起源の解明を行うこととした.

\section{b) 地下水の流動方向の把握}

調査結果より,地下水流動層が存在することが明ら かとなっており, 流動速度も非常に大きい（表一2 参 照).これに対して, ボーリング孔内水位の変動状況が 位置によって著しく変わっていることから, 地下水の 流動方向を把握する必要がある.
追加調査としては, 流向流速測定, トレーサー観測, 比抵抗二次元探査を実施し, 地下水の流動方向を把握 することとした.

\section{4. 地下水起源の解明と地すべり発生原因と被压 地下水の関係}

\section{(1) 水収支からの地下水起源の推定}

前章で問題となった地すべり地内の地下水が, 周辺 集水領域の雨水による浸透水のみか, 他の領域からの 供給（深層地下水を含む）が関与するのかを確認する 必要がある. そこで, 本報告では, 地すべりブロック内 の水収支について, 地下水位の上昇から推定される地 下水体積と地すべりブロック内及び背後の急斜面に降 った雨から供給される水の体積の差を算出することで 検討した.なお, 検討期間は観測期間中に本調査地にお いて最も大きな降雨が発生した昭和 39 年 7 月 7 日〜 19 日とした. 
表一3 水位上昇による地下水体積の推定

\begin{tabular}{c|c|c|c|c}
\hline $\begin{array}{c}\mathrm{A} 0 \text { ブロック } \\
\text { 集水面積 } \\
\mathrm{S}_{\mathrm{A0}}\left(\mathrm{m}^{2}\right)\end{array}$ & $\begin{array}{c}\text { ボーリング } \\
\text { 番号 }\end{array}$ & \multicolumn{3}{|c}{ 昭和39年7月7日 降雨前の } \\
水位 $(\mathrm{m})$ & $\begin{array}{c}\text { 降雨後の } \\
\text { 水位 }(\mathrm{m})\end{array}$ & 水位差 $(\mathrm{m})$ \\
\hline \hline \multirow{5}{*}{36000} & $\mathrm{~B} 2-1$ & -12.00 & -3.52 & 8.48 \\
& $\mathrm{~B} 2-2$ & -14.00 & -0.62 & 13.38 \\
& $\mathrm{~B} 2-3$ & -9.80 & -1.04 & 8.76 \\
& $\mathrm{~B} 2-4$ & -6.50 & -0.73 & 5.77 \\
& $\mathrm{~B} 2-19$ & - & - & - \\
& $\mathrm{B} 2-21$ & - & - & - \\
& $\mathrm{B} 2-22$ & - & - & - \\
& 差の平均 $\mathrm{H}$ & & & 9.1 \\
\hline \hline
\end{tabular}

表-4 降水量からの地下水体積の推定

\begin{tabular}{c|c|c|c}
\hline \multicolumn{2}{c|}{ 集水面積 $\mathrm{S}_{\mathrm{A} 0} \mathrm{~S}\left(\mathrm{~m}^{2}\right)$} & \multicolumn{2}{l}{ 昭和39年7月7日 19日の期間 } \\
\hline \hline $\begin{array}{c}\mathrm{A} 0 \\
\text { ブロック } \\
\mathrm{A} 0\end{array}$ & 36000 & & \\
ブロック背面 & 34000 & 累積降水量 $\mathrm{R}(\mathrm{m})$ & 0.673 \\
\hline
\end{tabular}

地下水位の上昇から推定される地下水の体積は, 次 式により算出した. 算出結果を表一 3 に示す.

$$
V a=S_{A 0} \times n \times \bar{H}
$$

ここで,

$V a$ : 地下水位の上昇加推定される地下水体積 $\left(\mathrm{m}^{3}\right)$

$S_{A 0}:$ A0 ブロックの集水面積 $\left(\mathrm{m}^{2}\right)$

$n:$ 空隙率

$\bar{H} \quad$ : 各ボーリング孔の地下水位の平均 $(\mathrm{m})$

地すべりブロック内及び背後の急斜面に降った雨か ら供給される水の体積は, 次式により算出した. 算出結 果を表一4に示す.

$$
V b=\left(S_{A 0}+S\right) \times R
$$

$$
\text { ここで, }
$$

$V b$ ：地す心゙りブロック内及び背後の急斜面に降つ た雨から供給される水の体積 $\left(\mathrm{m}^{3}\right)$

$S: A 0$ ブロック背後の集水面積 $\left(\mathrm{m}^{2}\right)$

$R$ : 累積降水量 $(\mathrm{m})$

表一 3 , 表一 4 から明らかなように, 水位上昇から推定 される地下水の体積 $\left(65,520 \mathrm{~m}^{3}\right)$ に対して, 降水量から

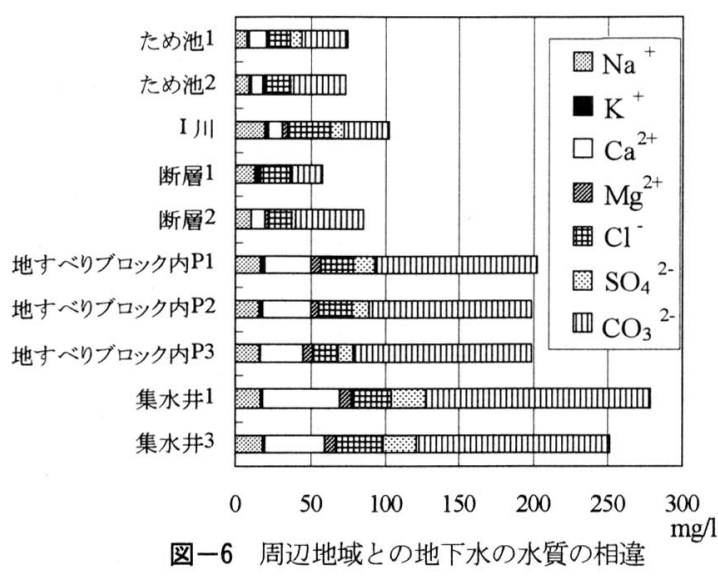

推定される地下水の体積 $\left(47,110 \mathrm{~m}^{3}\right)$ は, $18,410 \mathrm{~m}^{3}$ も不 足していることが分かる.すなわち, 地すべりブロック 内及び集水域に降った降雨のみでは，地すべりブロッ ク内の地下水位の上昇に見合うだけの水量を補うこと は不可能であることが判明した．したがって，地すべ りブロック内の地下水は, 集水域よりもさらに背後，あ るいは深層地下水（被圧地下水）からの供給が推定さ れた. 例えば, 地すべり地の背後にあるため池（図一1 参照）は，地すべりブロックよりも高標高にあり，た め池功の地下水供給も一因として考えられた.

\section{(2) 水質分析等による地下水起源の推定}

次に地すべり地内の地下水を用いて, 水質分析 ${ }^{4)}$ と 年代測定を実施し, 地下水起源の解明を行った. 水質分 析で用いた試料は, 地すべりブロック内 5 籄所, 地す べり 周辺部 4 箇所, I 川の計 10 箇所から試料を採取し た. 試料採取位置は図一 1 及び図一 2 に位置を示してい る. 分析結果を図一6に示す. 図一6より，地すべりブ ロック内の試料とそれ以外の試料では溶存イオン量で 明確に区分されることがわかる. 特に $\mathrm{Ca}^{2+}, \mathrm{SO}_{4}^{2-}, \mathrm{CO}_{3}{ }^{2-}$ の溶存量の差異が顕著である．地すべりブロック内の 涌水のイオン溶存量は，集水井の地下水とほぼ同等の 值だが, 少なくとも, ため池等の周辺地域に分布する表 層水とは異なることが判明した。

更に, 地すべり地内の地下水の年代測定を行った.こ の手法は，降水中に含まれるトリチウムの放射能濃度 との比較によって分析する手法 ${ }^{5)}$ である. 分析結果よ り地下水の年齢は約 10 年という結果となり, 水質分析 の結果とあわせて考えると，地すべり地内の地下水が， 雨水の浸透水を主体とする浅層地下水とは考えにくい 結果となった。これらの結果及びボーリング調查や比 抵抗二次元探査結果より, 地すべり地内の地下水は, 地下深部に長期に滞留する樑層地下水であることが判 明した。 

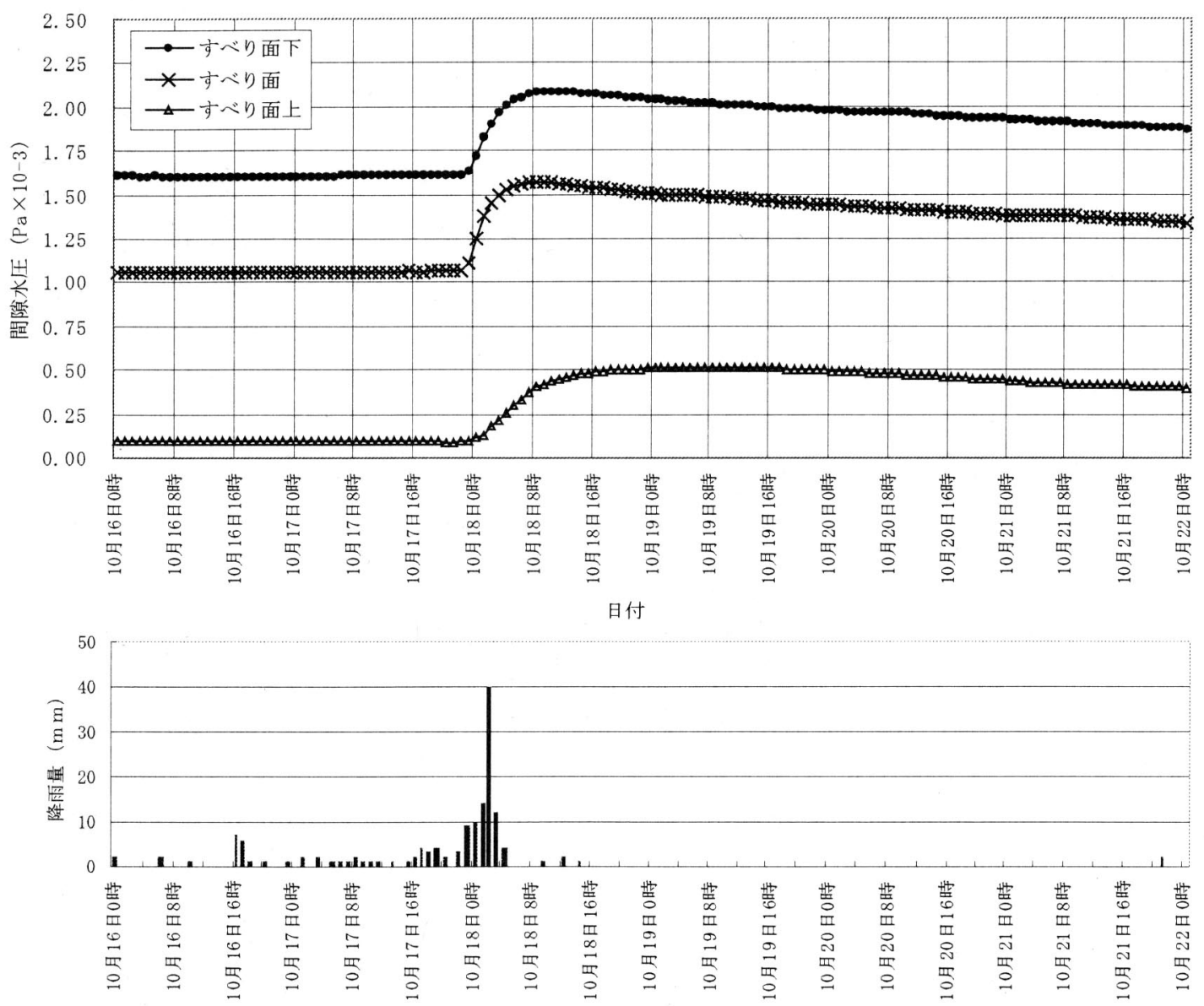

図ー7 豪雨時のすべり面付近における間隙水圧の変動（1998 年 10 月 16 日 0 時〜1998 年 10 月 22 日 0 時）

\section{(3)Ｉ地区の地すべりの特徵と被圧地下水の関係}

すべり面周辺で発生する間隙水圧の挙動を明確にす る目的で, すべり面付近に 3 箇所（すべり面上位，すべ り面，すべり面下位）間隙水圧計を設置し，その変化 を調査した（観測位置は図－2）。図７に間隙水圧の 変動を示す. 図ー7 より, 普段は同じような変動を示し ていた間隙水圧が, $100 \mathrm{~mm}$ 以上の豪雨時には 3 箇所の 間隙水圧計の内, す心゙り面下位とす心゙り面の值が最初 に反応し，ピークに達したのに対し，すべり面上位では 遅れて反応した. また, 降雨を経験してから間隙水圧が ピークに達するまでの時間に着目すると, すべり面上 位では 16 時間を要するのに対し,下位では 8 時間と 2 倍速く, 間隙水圧の值も大きいことが分かる.これは, すべり面下位に滞留する深層地下水が, 常に被圧され ているためと考えられる.一般的に被圧地下水は, 不圧 地下水に比べて圧縮率が高いため, 圧力水頭の伝播速 度が速く, 水の供給源が遠方でも影響が及ぶといわれ
ている ${ }^{5)}$.したがって, 豪雨時に, 供給域の水圧上昇が発 生した場合, より圧縮されていたすべり面下位の被圧 地下水が, すべり面上位の水圧より早く伝播し, 急激な 間隙水圧の上昇を招いたと考えられる.

本調査地域におけるすべての調査結果より, I 地区に おける地すべりの特徴として次のことが挙げられる.

・この区域は, 断層破砕帯が多く存在し, 地下水 等の影響により風化が著しいなど, 地質的に 劣悪である

- 地下水の分布が流動状況を複雑なものにして いる

- 豪雨時には, すべり面下位の被圧地下水圧が 急激に上昇し，すべり面に作用するため，すべ り面のせん断抵抗力は大幅にかつ急激に低下 する 


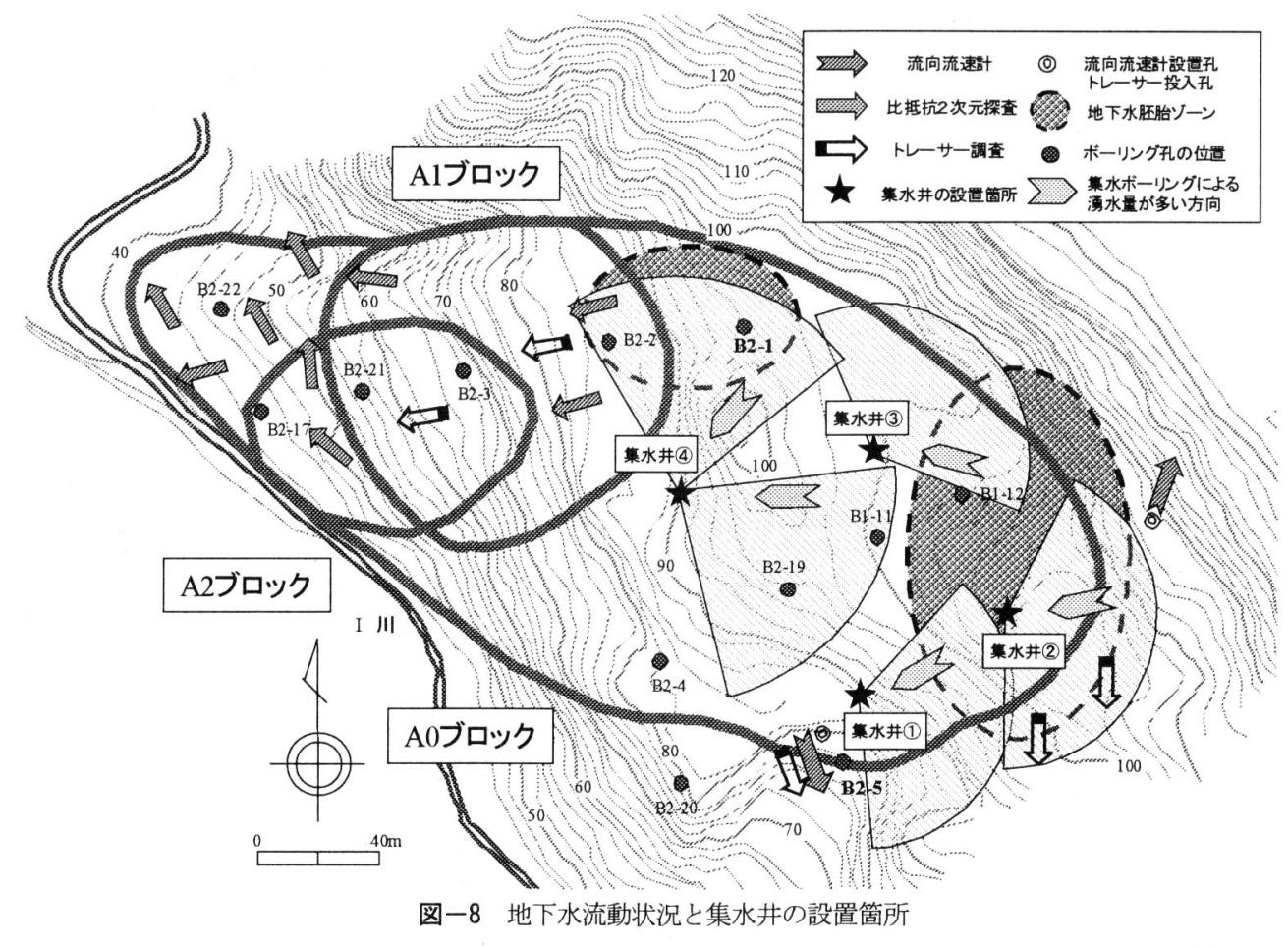

\section{5. 地下水流動状況の把握と対策工の効果}

本調査地域では, 地下深部の被圧地下水が地下水位 に影響し, 地す心゙り発生の一因であると考えられるた め, これらを取り除くことが, 地下水位の低下（地す心 りの安定化)に有効であると判断した. 特に被圧の問題 が明らかとなった A0, A1 ブロック頭部には, 地下水を 多く胚胎するゾーン（以下，「地下水胚胎ゾーン」と表 記）が存在する.したがって, A0, A1 ブロック頭部では, 集水井の深度を可能な限り深くし，すべり面を切って 集水ボーリングを施工することにより,す心゙り面下位 の被圧地下水を排除する必要がある.

したがって, 地下水排除計画は, 被圧地下水を集中的 に排除できるように集水井の施工位置, 施工深度を設 定した. また, 集水井は, 上記の内容を踏まえて, 平面的 に見て地すべりブロック全体にまんべんなく配置を行 らこととした.また, 集水ボーリング（図－8の扇形の 範囲）は, 地下水胚胎ゾーンが存在する方向とし, 断面 的には地下水流動層を狙って施工した.

\section{（1）集水井(1)，集水井(3)の先行施工}

まず, 集水井の効果の確認と以下に示す理由によ り, A0 ブロック頭部で 2 䇢所 (集水井(1)と集水井(3) 先 行して設置した. 2 基の集水井の位置を図ー8 に示す.

集水井(1)は,ボーリング孔 B2-5 に近接してい る. B2-5 では, 水位観測結果より降雨に関係なく常に高
い水位を維持していることから, 谷部に地下水が集中 していると考えられた. また, この領域は, 道路計画で は盛土区間となることから, 盛土の安定には早急に地 下水位を低下させる必要があるため, 設置を優先させ た.集水井(3に関しては, 地す心゙り面までの樑さが最も 深い位置であり，集水井を最も梁く施工できることか ら, 被圧地下水を大幅に排除できると考え, 先行して設 置した.

集水井(1), 集水井(3)を先行して設置した結果，ともに 集水ボーリングからの湧水が確認された. その水量は, 掘削終了直後それぞれ $20 \sim 100 \mathrm{l} / \mathrm{min}$ (集水井(1)，10 $\sim 80 \mathrm{l} / \mathrm{min}$ (集水井(3) であり, 特に地下水胚胎ゾーン (図-8 の点線の囲み) 向きの集水ボーリングでは, 湧 水量が大であった. また,この 2 基の集水井掘削によっ て, 地す心゙り頭部付近の地下水位は低下しており，集 水井の効果は確認できたといえる. 集水井設置後の地 下水位変動状況を図一9に示す. 图一9には, A0 ブロッ ク頭部付近のボーリング孔での水位変動を示している. 図-9より, B2-1 では, 図-4 と比較すると, 明確に地下 水位が低下しているのが分かる. しかし， B2-5につい ては, 集水井(1)を施工したにもかかかわ加ず, ほとんど水 位に変化が見られなかった。 


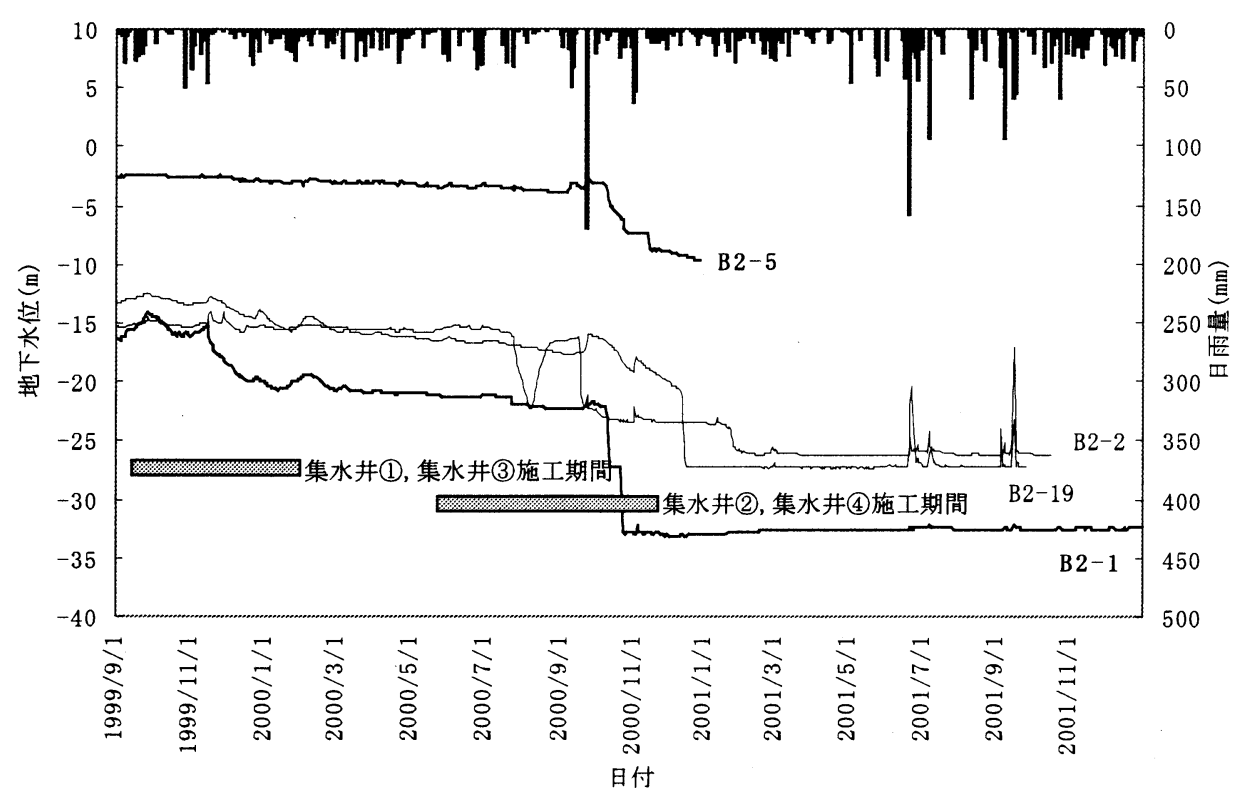

図-9 対策工の施工状況と地下水位変動の関係（B2-1, B2-2, B2-5, B2-19）

\section{（2）集水井(2), 集水井(4)の整備}

集水井(1)，集水井(3)の地下水位の影響範囲等を踏ま えて, もう 2 基の集水井の設置位置を検討した. $\mathrm{A} 0 フ ゙$ ロック頭部の地下水胚胎ゾーンに 1 基(集水井(2)， $\mathrm{A} 1$ ブロック頭部の地下水胚胎ゾーンの地下水排除及び $\mathrm{A} 0$ ブロック全域にかけての地下水排除を兼ねて 1 基(集 水井(4))集水井を設置する計画に修正した.

集水井設置箇所の選定は，ボーリングで観測された 水位, 地下水検層結果等によって地下水が流動してい るゾーン (図ー3 参照) を把握し, この流動層の水を もつとも効率的に抜くことができるような位置を抽出 した.

また, 集水井(1)及び集水井(3)と同様に, すべり面を切 って背後の地山まで集水ボーリングを伸ばし, 被圧地 下水を根底から排除することとした.

集水井(2)及び集水井(4)の効果は, 図一9に示した施工 後の地下水位変化より確認できる. 集水井(2)及び集水 井(4)の湧水量は, 掘削直後でそれぞれ 100〜220l/min (集水井(2)，200～320l/min (集水井(4)）であり, 排水 効果は十分であることがわかる.これらの集水井によ って, ボーリング B2-1 の地下水位は, 顕著にその影響 を受けて, 大幅に低下している.また, B2-5については, 集水井(3の施工で地下水位の低下が見られなかったが, 今回の集水井(4)の施工によって, $5 \mathrm{~m}$ 程度の地下水位の 低下が確認できた. このことから, B2-5 付近の地下水 は, 地形の傾斜方向と異なる動きをしていると考えら れる.

\section{(3) 地下水流動方向の把握と効率的な集水井の配置}

地下水がどの方向に流動しているのかを確認するた めに, 流向流速調查 ${ }^{4)}$, トレーサ一調査 ${ }^{4)}$, 比抵抗二次 元探査を行った. また, トレーサーは, ボーリング孔だ けでなく,集水ボーリングにおいても確認し, 地下水の 流動方向の把握を行った. それらの観測結果は図一8の 矢印で示している.

また, 図ー8 の地下水胚胎ゾーン(図-8 の点線の囲 み）は, 次の 6 点から推定を行った.

(1)地すべりブロック内で実施した比抵抗二次元探査で 比抵抗値の低い範囲の面的断面的な分布状況

(2)集水井施工時の集水ボーリングで湧水が多く確認 された方向

(3)トレーサー調査や単孔での流向流速測定結果 (4)地下水検層で確認された地下水流動層の分布 (6)弾性波探査で確認された基板岩の形状

図一8より,地すべり地内の地下水の流動方向は基本 的に A0 ブロック頭部の地下水胚胎ゾーンから地形に 沿って南西から西に向かって流れ下っているが，地す ベりブロック A1 末端部付近から I 川の流下方向に向き を変えていることが分かる. また, $\mathrm{A} 0$ ブロック頭部に 設置した流向流速計では, 一部の地下水が山側に向か っており, 更に集水井(2)の南側の集水ボーリングでト レーサーが確認されたことから, 地下水胚胎ゾーンか ら放射状に地下水位が流動していることが判明した. さらに, 流向流速計及びトレーサー調查結果, B2-5 付近 では, 流動方向が南向きであることが示された.このこ 
とは，B2-5 の孔内水位が集水井(1)設置後にほとんど 変動しなかったことと, 集水井(4)の設置後に緩やかに 地下水位が低下したことに一致している.

これらのことから, 効率的に集水井を配置するには, 地下水流動方向の把握が不可欠であることが改めて確 認できた.

集水井を 4 基設置した後も，地下水位観測は引き続 き行われているが，地すべり頭部では対策工施工前と 比較して $10 \mathrm{~m}$ 以上もの地下水位低下の効果が確認され ている (図一9参照)。計画されていた水位低下量は $3 \mathrm{~m}$ を目標としていたため, その目的は十分に達成された といえる. また, 本報告では, 集水井の施工において, 水位低下 $3 \mathrm{~m}$ を目安としたが, 実際の地下水位の低下状 況は, 事前の地下水観測により把握し,その結果を計画 に反映させた. 更には, 集水井を試験的に実施するとと もに, 施工後の効果を水位観測で確認しながら, 施工計 画の見直しを行うことで,より効果的な配置計画につ ながったものと考える.

一部の観測孔で豪雨後に地下水位が急激に上昇する ものの, 地下水位のピーク值は集水井施工前に比べる と低く,かつ短時間で基底水位まで低下することから， 特に問題にはならないと考えている.

\section{6. おわりに}

本報告では地すべり地での詳細な地下水動態調査結 果に基づいた集水井施工計画の検討事例を紹介した. ボーリング調査, 地下水調査等の基本的な調査の重要 性，そして効果的な集水井施工のためには地下水の分 布と流動状況を把握する必要性が明らかとなった．以 下に本報告において得られた結論をまとめる.

1）本報告では， I 地区の地すべりは劣悪な地質状況に 加えて, 地すべりブロック周辺の多量に存在する 地下水の影響が原因であることを明確にした. 特 にすべり面下位の被圧地下水が, 豪雨時にすべり 面の急激なせん断抵抗力の低下を招くため, 地す べり発生の主要因であることが判明した.

2）本調査地では詳細な地下水調査結果から, 地下水 流動層及び被圧地下水の分布を十分把握した上で, 集水井を配置した. その結果, 地すべり頭部では, 集水井施工前と比較して $10 \mathrm{~m}$ 以上もの地下水位が 低下し, 地すべり発生の危険度が大幅に減少した。

3）水収支, 水質分析, 年代測定, 比抵抗二次元探査結 果を総合的に判断した結果, 本報告では, 地すべり 地内の地下水起源を被圧地下水と断定した.この 結果を踏まえて, 集水井の施工深度を被圧地下水
まで伸ばすことで, 効果的な地下水排除が可能と なった.

4）本調査地では, 集水井の施工において, 集水井を試 験的に実施するとともに, 施工後の効果を水位観 測で確認しながら, 施工計画の見直しを行うこと で,より効果的な配置計画とすることができた.

5）すべり面下位に被圧地下水が滞留する場合, 遠方 の供給域で発生した水圧が, 圧縮率の高い被圧地 下水中を速く伝播するといわれている. しかし, 実 際にそのような現象が報告された例は少ない. 本 報告では, すべり面付近の間隙水圧を測定した結 果, 豪雨時にすべり面下位の間隙水圧が上位の水 圧に比べて急激に増大した.このように間接的で あるが前述した被圧地下水圧が, 降雨時に急上昇 する現象を間隙水圧を通じて示すことが出来た.

謝辞 : 本研究を行うにあたり, JH 松江工事事務所の村 田一廣氏, 寺本丈夫氏, 藤沢茂樹氏にはデータの収集や とりまとめに際し,多大な貢献をいただきました. 株式 会社エイトコンサルンタントの佐藤丈晴氏には本論文 のとりまとめに際して,多くのご意見をいただきまし た.ここに媣甚なる謝意を表します.

\section{参考文献}

1）建設省砂防部：砂防便覧（平成 11 年度版), 社団法人全 国治水砂防協会, 2000 .

2）池谷浩, 吉松弘行, 南哲行, 寺田秀樹, 大野宏之: 砂防 - 地 すべりがけ崩れ・雪崩防止工事ポケットブック，山海堂, 2001.

3）藤原明敏 : 地すべりの解析と防止対策, 理工図書, 1983.

4）財団法人国土開発技術研究センター: 地下水調查および 観測指金十(案), 山海堂, 1996.

5）山本痣毅：新版地下水調查法, 古今書院, 1983.

6）寺川俊浩 : 地すべり地における地下水調查法と地下水排 除工の設計（その1），地すべり技術，Vol. 24，No.1， 1987.

(2002. 9.20 受付) 


\title{
AN EXAMPLE OF GROUNDWATER SURVEY FOR GROUNDWATER \\ DRAINAGE WORKS IN LANDSLIDE AREA
}

\author{
Atsukuni KAJIMA, Hiroaki TAKEMOTO, Takayuki HARUGUCHI, \\ Yasushi SASAKI, Seishi OKUZONO and Kohei FURUKAWA
}

For the reason that geology condition is complicated, generally speaking, it is very difficult to understand streaming distribution and the condition of groundwater in landslide area. Construction of road in the landslide area has possibility to cause landslide disaster. It is very important for landslide investigation to understand the groundwater condition to prevent the area from landslide disaster.

An example of the most suitable planning for the countermeasure of landslide by the detailed groundwater survey is reported in this paper. 